\title{
Fibrinolytic activity of tissue surfaces during surgery
}

\author{
A. J. DAVIES, C. J. L. STRACHAN ${ }^{1}$, R. A. HURloW, AND J. STUART \\ From the Departments of Haematology and Surgery, Queen Elizabeth Hospital, Birmingham B15 2TH, UK
}

SUMMARY A non-invasive method has been developed for the study of tissue surface fibrinolytic activity during surgery in man. Surface exudate was collected using a filter-paper disc which was then applied directly to a fibrin plate or used to prepare a euglobulin fraction. The method detected the intraoperative increase in fibrinolytic activity. At 45 minutes from the start of surgery the increase in lytic activity for tissues was four to eight times greater than that of venous blood taken simultaneously. The technique may be used to compare regional differences in tissue fibrinolysis, to determine the effect of excess local fibrinolysis on postoperative bleeding, and to study the relation between low fibrinolytic activity and postoperative adhesion formation.

Measurement of the surface fibrinolytic activity of tissues during surgery is of potential importance since an increase in local, rather than systemic, fibrinolysis may contribute to postoperative bleeding. Umlas (1976) demonstrated increased fibrinolysis within the chest, but not in systemic blood, after thoracotomy, and Nilsson (1975) described local fibrinolysis as a contributory cause of bleeding from many organs. Conversely, a reduction in local fibrinolytic activity may cause postoperative adhesions within the abdomen (Gervin et al., 1973).

Previous studies of tissue fibrinolysis have usually employed an invasive biopsy technique. Plasminogen activator may either be extracted from the tissue sample (Astrup and Albrechtsen, 1957) or measured by applying a tissue fragment to a fibrin plate (Permin, 1947) or by placing a tissue section on a fibrin-coated glass slide (Todd, 1959). As an alternative to these invasive techniques, Raftery (1977) used a gelatin disc to transfer a single-cell layer of endothelium or mesothelium to a fibrin plate in an experimental study on rats.

Fibrinolytic activity in the external secretions from a discharging wound has been studied in man by absorption of activator using a filter-paper (Björlin and Nilsson, 1968) or gauze (Birn, 1970) strip or by using beads of hydrophilic dextran polymer (Âberg et al., 1976). We have studied the surface secretions of internal tissues during surgery in man and have developed a sterile, filter-paper disc

${ }^{1}$ Present address : Division of Surgery, Brighton General Hospital, Brighton, UK

Received for publication 31 January 1979 method to absorb and transfer these secretior $s$ either directly to a fibrin plate or via the intermediate preparation of a euglobulin fraction.

\section{Methods}

PREPARATION OF FIBRIN PLATES

A modification of the method of Astrup and Müllertz (1952) was used. Human fibrinogen, 250 mg of grade L (AB Kabi, Stockholm), was dissolved in $100 \mathrm{ml}$ of $0 \cdot 1 \mathrm{M} \mathrm{pH} 7 \cdot 3$ phosphate buffer; $5 \mathrm{ml}$ of the solution were pipetted into a $50 \times 13 \mathrm{~mm}$ plastic petri dish (Sterilin Ltd), and $0.1 \mathrm{ml}$ of $50 \mathrm{U} / \mathrm{ml}$ thrombin (Parke Davis) was added and thoroughly mixed. The fibrin plates were freshly prepared and allowed to stand at room temperature for 30 minutes before use. Plasminogen-free plates were prepared by heating to $80^{\circ}$ for 2 hours.

FILTER-PAPER DISCS

Discs of $13 \mathrm{~mm}$ diameter were cut from $3 \mathrm{MM}$ Whatman chromatography paper, using a no. 7 cork borer, and sterilised using ethylene oxide. A disc was applied, using sterile forceps, to a tissue surface during surgery and, when saturated with surface exudate, was pressed firmly for approximately 1 second between sheets of filter paper to remove excess fluid before being applied directly to a fibrin plate. Alternatively, a euglobulin fraction was prepared from the disc by immersing it in 0.9 $\mathrm{ml}$ cold distilled water, adding $0.01 \mathrm{ml}$ of $1 \%$ acetic acid, and allowing the precipitate to form at $\mathrm{pH} 5 \cdot 3$ and $4^{\circ}$ for 30 minutes with the disc in situ. After centrifugation at $1500 \mathrm{~g}(3000 \mathrm{rpm})$ for 10 minutes at $4^{\circ}$ the supernatant was decanted, residual fluid 
was carefully removed, and $0.03 \mathrm{ml}$ of $\mathrm{pH} 9.0$ borate buffer was added to dissolve the precipitate. The disc, now saturated with the euglobulin fraction, was then removed, pressed between filter paper sheets as before, and applied to a fibrin plate. Fibrinolytic activity was expressed as the product of two perpendicular diameters of the zone of lysis after incubation for 18 hours at $37^{\circ}$.

Tissue exudates were studied in patients undergoing cholecystectomy (10), laparotomy (1), and aortic valve replacement (3). Patients undergoing abdominal surgery were given 5000 units of subcutaneous heparin 1-2 hours preoperatively. Discs were applied to the cut subcutaneous fat, exposed after incision to the rectus sheath by a paramedian approach, after diathermy haemostasis. Further samples were taken from the surface of the exposed uncut rectus abdominis muscle. At closure, discs were applied to the muscle after peritoneal closure and to the subcutaneous fat after sheath suture.

In the cholecystectomy patients, discs were also applied to the gall bladder bed, and in three patients fibrinolysis was measured from samples obtained from the uncut surface of the liver and omentum. In the three patients undergoing aortic valve replacement, the subcutaneous fat from a median sternotomy wound was sampled at 30-minute intervals, and further samples were obtained from the cut sternum, pleura, pericardium, and surface of the heart after 45-60 minutes from the start of thoracotomy.

Statistical significance was determined using Student's $t$ test for paired samples, and precision by coefficient of variation (CV).

\section{Results}

The precision of the disc technique was determined in vitro by repeated subsampling from an aliquot of citrated venous blood. The mean volume of blood subsampled in 20 replicate tests, determined by weighing the discs before and after saturation, was $0.034 \mathrm{ml} \pm 0.002 \mathrm{SD}$ (CV $5.8 \%$ ). When the discs were applied to fibrin plates the mean zone of lysis for the 20 tests was $269 \mathrm{~mm}^{2} \pm 14 \cdot 2$ (CV 5.3\%).

Precision in vivo was determined by sampling the exudate from subcutaneous fat, using 20 discs, at the onset of a cholecystectomy. The mean zone of lysis was $445 \mathrm{~mm}^{2} \pm 42 \cdot 5$ (CV $\left.9.5 \%\right)$ for 10 discs applied directly to fibrin plates and $365 \mathrm{~mm}^{2} \pm 30 \cdot 3$ (CV $7 \cdot 8 \%$ ) for 10 discs saturated with euglobulin fraction.

The intraoperative change in tissue surface fibrinolytic activity with time was studied by serial sampling of the exudate from subcutaneous fat in the thoracotomy wounds of three aortic valve

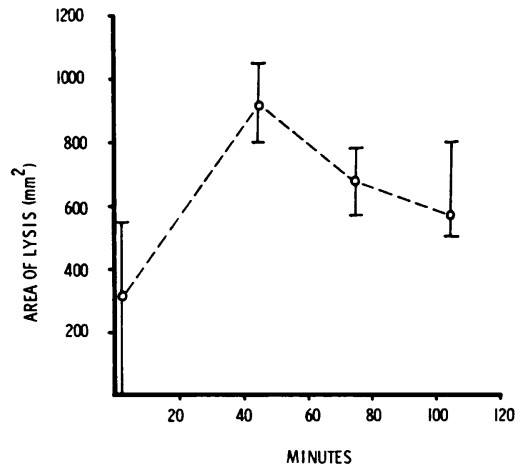

Fig. 1 Mean and range of lytic activity (direct method) in wound fat studied serially from start of thoracotomy in three patients undergoing aortic valve replacement.

replacements (Fig. 1). The maximum zone of lysis, for discs applied directly to fibrin plates, was obtained at 45 minutes from the start of the operation.

Surface fibrinolytic activity of fat and muscle in the abdominal wound at the beginning and end of 10 cholecystectomies and one laparotomy (average duration of operation 45 minutes) were compared using the direct application and euglobulin fraction methods (Fig. 2). The intraoperative increase in fibrinolytic activity was statistically significant $(P<0.01)$ for fat and muscle using both techniques. Systemic venous blood was taken simultaneously, citrated, and sub-sampled using the disc technique before application to fibrin plates. The mean increase in zone of lysis for the systemic blood at the end, compared with the beginning, of the operations (Fig. 2) was not statistically significant $(P>0 \cdot 1)$ for blood applied directly to the plates; the euglobulin fraction did give a significantly $(P<0.02)$ larger area of lysis at 45 minutes but this increase was half the mean increase in lysis for fat or muscle exudate.

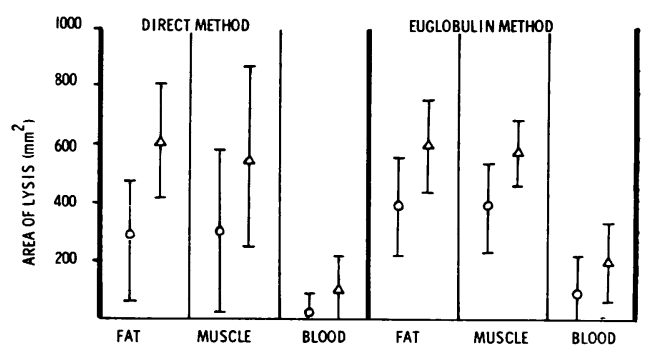

Fig. 2 Mean area $( \pm 1 S D)$ of lysis at the beginning $(O)$ and end $(\triangle)$ of 11 abdominal operations. Values for abdominal wall fat and muscle, obtained by the direct and euglobulin fraction methods, are compared with those for venous blood taken simultaneously. 


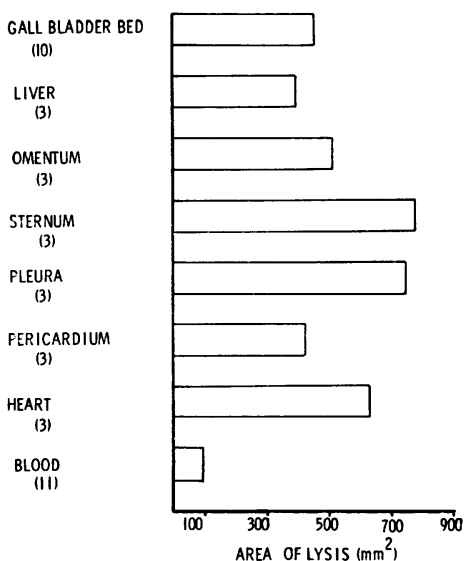

Fig. 3 Mean areas of surface lytic activity (direct method) for different tissues in comparison with systemic blood at 45-60 minutes from onset of surgery. Number of operations in parentheses.

Disc samples taken at one laparotomy were processed as before but applied to heated fibrin plates to test for the presence of free plasmin. None of these samples (from fat, muscle, and venous blood) caused any visible fibrin lysis.

Surface fibrinolytic activity was also studied in a variety of intra-abdominal and intrathoracic tissues at 45-60 minutes from the start of surgery. The variation in mean zone of lysis for the individual tissues, using the direct method, is shown in Fig. 3; in each case the tissue lytic activity was four to eight times that of venous blood taken at a comparable time.

\section{Discussion}

This simple, non-invasive technique for sampling tissue surface fibrinolytic activity during surgery eliminates the need for microtome sections of tissue biopsies. Unlike Raftery's (1977) gelatin disc, which removes a monolayer of tissue surface cells, the filter-paper discs sample tissue exudate only, and intact cells were not observed when disc imprints on glass slides were examined microscopically. The sterile paper discs, saturated with approximately $30 \mu \mathrm{l}$ of surface exudate, can be applied directly to a fibrin plate, or processed to yield a euglobulin fraction. Although the direct method gave a smaller zone of fibrinolysis than the euglobulin technique at the start of surgery, possibly reflecting fibrinolytic inhibitors in the directly applied and undiluted tissue exudate, the difference did not achieve statistical significance $(P>0 \cdot 1)$. Both methods, however, showed a similar area of lysis after 45 minutes, and any initial fibrinolytic inhibition appeared to be subsequently overwhelmed by the fibrinolytic response to surgery.

Increased surface fibrinolytic activity was found for all the tissues studied at $\mathbf{4 5}$ minutes from the onset of surgery. The increased activity at this time, for the direct method, varied from four to eight times the comparable activity of systemic venous blood. Thus the measurement of fibrinolytic enhancement during surgery is underestimated when systemic venous blood is sampled. An increase in local, but not systemic, fibrinolysis has previously been demonstrated in dental alveoli after tooth extraction (Björlin and Nilsson, 1968). Thoracotomy may also cause increased intrathoracic, but not systemic, fibrinolysis and result in a high level of fibrin degradation products in chest drainage fluid (Umlas, 1976).

An increase in local fibrinolysis may contribute to postoperative bleeding. The systemic use of a fibrinolytic inhibitor is, however, contraindicated when postoperative bleeding occurs into a closed compartment owing to the risk of unlysable clot forming. A local spray application of tranexamic acid, applied before wound closure, may assist haemostasis, although experimental studies will be required to ensure that temporary inhibition of surface fibrinolysis does not increase the incidence of subsequent postoperative adhesions (Gervin et al., 1973; Buckman et al., 1976).

We are indebted to the Central Birmingham Health District Trust Funds for financial support.

\section{References}

Åberg, M., Hedner, U., Jacobsson, S., and Rothman, U. (1976). Fibrinolytic activity in wound secretions. Scandinavian Journal of Plastic and Reconstructive Surgery, 10, 103-105.

Astrup, T., and Albrechtsen, O. K. (1957). Estimation of the plasminogen activator and the trypsin inhibitor in animal and human tissues. Scandinavian Journal of Clinical and Laboratory Investigation, 9, 233-243.

Astrup, T., and Müllertz, S. (1952). The fibrin plate method for estimating fibrinolytic activity. Archives of Biochemistry, 40, 346-351.

Birn, H. (1970). Fibrinolytic activity in 'dry socket'. Acta Odontologica Scandinavica, 28, 37-58.

Björlin, G., and Nilsson, I. M. (1968). Fibrinolytic activity in alveoli after tooth extraction. Odontologisk Revy, 19, 197-204.

Buckman, R. F., Woods, M., Sargent, L., and Gervin, A. S. (1976). A unifying pathogenetic mechanism in the etiology of intraperitoneal adhesions. Journal of Surgical Research, 20, 1-5.

Gervin, A. S., Puckett, C. L., and Silver, D. (1973). 
Serosal hypofibrinolysis: a cause of postoperative adhesions. American Journal of Surgery, 125, 80-88.

Nilsson, I. M. (1975). Local fibrinolysis as a mechanism for haemorrhage. Thrombosis et diathesis haemorrhagica, 34, 623-633.

Permin, P. M. (1947). Properties of the fibrinokinasefibrinolysin system. Nature, 160, 571-572.

Raftery, A. T. (1977). A method for measuring fibrinolytic activity in a single layer of cells (Abstract). British Journal of Surgery, 64, 825-826.
Todd, A. S. (1959). The histological localisation of fibrinolysin activator. Journal of Pathology and Bacteriology, 78, 281-283.

Umlas, J. (1976). Fibrinolysis and disseminated intravascular coagulation in open heart surgery. Transfusion, 16, 460-463.

Requests for reprints to: Professor J. Stuart, Queen Elizabeth Hospital, Edybaston, Birmingham B15 2TH, UK.

\section{Reports and Bulletins prepared by the Association of Clinical Biochemists}

The following reports and bulletins are published by the Association of Clinical Biochemists. They may be obtained from The Publishing Department, British Medical Journal (ACB Technical Bulletins), B.M.A. House, Tavistock Square, London WC1H 9JR. Overseas readers should remit by British Postal or Money Order.

SCIENTIFIC REVIEWS (price $£ 1 \cdot 00 / \$ 2.00$ each)

1 The assessment of thyroid function March 1971 F. V. FLYNN and J. R. HOBBS

2 Renal function tests suitable for clinical practice January 1972 F. L. MITCHELl, N. VEALL, and R. W. E. WATTS

3 Biochemical tests for the assessment of fetoplacental function May 1975 C. E. WILDE and R. E. OAKEY

4 Test of exocrine pancreatic function March 1977 A. H. GOWENLOCK

5 Assay of cholinesterase in clinical chemistry March 1979 ELSIE SILK, J. KING, and MARY WHITTAKER

TECHNICAL BULLETINS (price $£ 1 \cdot 00 / \$ 2.00$ each)

22 Bilirubin standards and the determination of bilirubin by manual and technicon AutoAnalyzer methods January 1971 BARBARA BILLING, RUTH HASLAM, and $\mathrm{N}$. WALD

23 Interchangeable cells for spectrophotometers and fluorimeters September 1971 S. S. BROWN and A. H. GOWENLOCK

24 Simple tests to detect poisons March 1972 B. W. MEADE et al.

25 Blood gas analysers May 1972 K. DixON

26 Kits for enzyme activity determination September 1972 S. B. ROSALKI and D. TARLOW

27 Assessment of pumps suitable for incorporation into existing continuous flow analytical systems November 1972 A. FLECK et al.
28 Routine clinical measurements of transferrin in human serum September 1973 K. DIXON

29 Control materials for clinical biochemistry (5th edition) September 1973 J. F. STEVENS

30 Notes on the quality of performance of serum cholesterol assays September 1973 S. S. BROWN

31 Determination of uric acid in blood and in urine July 1974 R. W. E. WATTS

32 A survey of amino acid analysers readily available in the United Kingdom September 1974 J. E. CARLYLE and P. PURKISS

33 Definitions of some words and terms used in automated analysis November 1974 A. FLECK, R. ROBINSON, S. S. BROWN, and J. R. HOBBS

34 Measurement of albumin in the sera of patients January 1975 LINDA SLATER, P. M. CARTER, and J. R. HOBBS

35 Investigation of the validity of temperature correction factors for serum aspartate and alanine transaminases March 1975 s. B. ROSALKI et al.

36 Factors influencing the assay of creatinine November 1975 J. G. H. COOK

37 A survey of enzyme reaction rate analysers readily available in the United Kingdom July 1977 R. A. SAUNDERS and R. F. BLRNS

38 Transport of specimens for clinical chemistry analysis November 1977 P. WILDING, J. F. ZILVA, and c. E. WILDE

39 A scheme for the evaluation of diagnostic kits May 1978 P. H. LLOYD 